International Journal of Instruction e-ISSN: 1308-1470 • www.e-iji.net

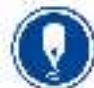

April 2021 • Vol.14, No.2

p-ISSN: 1694-609X

pp. 1037-1050

Article submission code

20200625033835

Received: 25/06/2020

Revision: $15 / 11 / 2020$

Accepted: 06/12/2020

OnlineFirst: 25/03/2021

\title{
Assessing Verbal Positive Reinforcement of Teachers during School from Home in the Covid-19 Pandemic Era
}

Mantasiah R.

Prof., Universitas Negeri Makassar, Indonesia, mantasiah@unm.ac.id

Yusri

Universitas Negeri Makassar, Indonesia,yusri@unm.ac.id

Abdullah Sinring

Universitas Negeri Makassar, Indonesia, abdullah.sinring@unm.ac.id

Farida Aryani

Universitas Negeri Makassar, Indonesia,farayani77@yahoo.com

During school from home, students need positive reinforcement both from parents and teachers to improve or trigger their positive behavior. This study aimed to identify the intensity of verbal positive reinforcement given by teachers to students during school from home. It was a mix-method study by involving 310 elementary school teachers as respondents ( $41.29 \%$ males, $58.71 \%$ females). The intensity of positive reinforcement was measured using an instrument developed from the basic theory of positive reinforcement by Skinner (1953) and Schakel \& Lyon (1984) and information collected from interviews with teachers. The instrument consisted of 7 kinds of verbal positive reinforcement that can be given by teachers during school from home. The findings indicated that during school from home, teachers tended to give less verbal positive reinforcement to students. Teachers' lack of understanding about the importance to give positive reinforcement during school from home was the main factor leading to the condition. Besides that, teachers did not understand that the verbal positive reinforcement can be delivered both in oral and written forms. Another finding shows that female teachers more often gave positive reinforcement than males. The kind of positive reinforcement given by these two different genders was also different.

Keywords: positive reinforcement, verbal positive reinforcement, school from home, communication style, teachers

\section{INTRODUCTION}

Coronavirus disease 2019 (COVID-19) has become an urgent topic to carry out in the areas of health (Chen et al., 2020; Onder et al., 2020), social (Prem et al., 2020),

Citation: Mantasiah, R., Yusri., Sinring, A., \& Aryani, F. (2021). Assessing Verbal Positive Reinforcement of Teachers during School from Home in the Covid-19 Pandemic Era. International Journal of Instruction, 14(2), 1037-1050. https://doi.org/10.29333/iji.2021.14259a 
technology (Ting et al., 2020; Wang et al., 2020), economic (Altig et al., 2020; Nicola et al., 2020), education (Van Lancker \& Parolin, 2020; Rundle et al., 2020), and so on. Those studies investigated Covid-19 to find out a vaccine for curing the patients of Covid-19, strategies to prevent the spread of the virus, and impacts of this plague in various life sectors. To solve these problems, the government did not only focus on curing the patient of COVID 19 but also on the prevention acts.

Each country applied some strategies to prevent the spread of the virus. One of them, in the educational sector, was the policy of School from Home (SFH). It regulated all learning process not conducted at school, but at home via online. It is one of the social and physical distancing strategies that has been proven able to cut the spread of Covid19 (Greenstone \& Nigam, 2020; Prem et al., 2020; Courtemanche et al., 2020). The implementation of the policy of school from home was quite incidental so that schools, teachers, students, and parents were not well prepared for this. It caused the program to experience various problems. The preliminary study shows that during school from home, students complained saturated because they felt bored to be at home, got too much task from their teachers, and they often found unclear instruction from teachers related to their task. As a consequence, students felt stressed undergoing the school from home programs. Besides that, parents also complained about difficulties to accompany their children studying at home, as they automatically get additional duties during the implementation of this policy (Purwanto, 2020; Viner et al., 2020; Wang et al., 2020).

One of the strategies that can be applied by teachers to reduce students' stress during school from home is by giving them positive reinforcement. Positive reinforcement is teachers' responses to students' positive behaviors so that students can increase their frequency to perform them. Some earlier studies showed the effectiveness of the application of positive reinforcement in boosting students' positive behavior in the learning process (Sigler \& Aamidor, 2005; Uddin et al., 2017; Hardy \& McLeod, 2020; Sumiati et al., 2019). The positive reinforcement can be applied in various forms like giving a present, award, or oral and written compliments. Therefore, positive reinforcement is essential to be applied by teachers during school from home.

Hoque (2013) states that one of the essential elements in the teaching process is providing reinforcement to students. Therefore, the skill of giving reinforcement must be mastered by the teachers because the reinforcement given to students can increase student motivation. Similiarly, Murni (2010) explains that reinforcement is a positive response by teachers for positive behavior achieved by students in the learning process. It aims to maintain and enhance the student's positive behavior. Therefore, it can be concluded that the purpose of giving positive reinforcement to students is to maintain positive behavior that has been done by students. Studies conducted by Hulac et al. (2016), Kodak et al. (2007), Bernier, Simpson, \& Rose (2012) show that there are several benefits of giving positive reinforcement to students in learning process, 1) Increasing student concentration, 2) Triggering and increasing student motivation, 3) increasing student self-esteem, 4) enhancing positive relationships between teachers and students. 
Murni (2010) explains that there are several principles of giving positive reinforcement including a) sincerity; b) enthusiasm; c) meaningfulness; d) avoid negative responses; e) reinforcement given immediately; f) reinforcement that is given variously. Reinforcement must be given with sincerity, without sincerity, giving reinforcement will not have a positive impact on students. In addition, the teacher must also show an enthusiastic attitude in giving reinforcement. This can encourage the emergence of pride and self-confidence in students. Another principle is meaningfulness. The main focus on this principle is that students understand and believe that they are indeed worthy of reinforcement because this is following their behavior.

The next principle is to avoid negative responses. Teachers must ensure that positive reinforcement given to students will not cause negative responses from students, such as reducing student motivation or making students feel offended. In addition, reinforcement will be more effective if it is given directly after students show positive behavior than waiting a few days later. It is related to the right moment in providing reinforcement. The last principle is that the reinforcement given must vary. There are various types of positive reinforcement, both verbal and non-verbal. The teacher can provide a variety of positive reinforcement to students so that students do not feel bored with the reinforcement.

In general, there are four types of reinforcement, including natural reinforcers, social reinforcers, tangible reinforcers, and token reinforcers. Natural reinforcers mean that students will naturally get output from their behavior like when a student is diligent in studying, she/he will get a good score. Tangible reinforcers refer to physical rewards like giving a doll, stationery, meals, candies, or other interesting objects for students. Token reinforcers are points given to students like giving stars to students when performing a positive attitude during the learning process in the classroom. Social reinforcers mean to give appreciation to students either in oral or in written form like saying "good job" to students who show positive behaviors (Alberto \& Troutman, 2006; Zirpoli, 2005).

This study aimed at identifying how often teachers giving positive reinforcement to their students and kinds of challenges teachers found in giving positive reinforcement to students. However, this study limits the types of positive reinforcement on verbal only including oral and written forms such as a compliment, attention like asking condition, and motivation. These reinforcements are categorized as social reinforcers. These forms refer to verbal positive reinforcement as the supports are given through verbal communication. Although they are not physical presents, those verbal utterances are also positive reinforcement because they are stimuli needed by students during the learning process (Conroy et al., 2009; Kelly \& Pohl, 2018).

\section{METHOD}

\section{Research Design}

This study is mix-method by integrating survey and focus group discussion. Creswell and Clark (2017) tell that this methodology permits a more complete and synergistic 
utilization of data than do separate quantitative and qualitative data collection and analysis.

\section{Participants}

There were 310 elementary school teachers in South Sulawesi Province, Indonesia involved as participants. The participants were chosen using a purposive sampling technique. Before being engaged as participants, teachers were given a short explanation related to this study in the survey form. Participants were given consent form of their participation, and they have the right not to participate in this study. This study focused on learning at the elementary level because students in the group tend to need more attention compared to the ones at secondary levels (Cicekci \& Sadik, 2019). Therefore, in terms of needs, students at elementary levels more demand positive reinforcement in learning, but it does not mean that secondary school students do not need such support. Following are characteristics of research respondents:

Table 1

Characteristics of research respondents

\begin{tabular}{lll}
\hline Characteristics & & Percentage (\%) \\
\hline \multirow{2}{*}{ Sex } & Men & 41.29 \\
\cline { 2 - 3 } & Women & 58.71 \\
\hline \multirow{3}{*}{ Teaching Experience } & $<1$ year & 6.45 \\
\cline { 2 - 3 } & $1-5$ years & 30.65 \\
\cline { 2 - 3 } & $6-10$ years & 41.61 \\
\cline { 2 - 3 } Grade & $>10$ years & 21.29 \\
\cline { 2 - 3 } & High-Level Class (Grade 4-6) & 61.93 \\
\cline { 2 - 3 } & Low-Level Class (Grade 1-3) & 38.07 \\
\hline
\end{tabular}

The research respondents were quite varied in terms of genders, teaching experiences, and the grades they taught. Therefore, the findings of this study can be generalized to all elementary school teachers.

\section{Data Collection Techniques}

The survey was conducted to get quantitative data related to the intensity of teachers in giving verbal positive reinforcement to their students. The survey was spread online using google form during a month. Focus group discussion (FGD) was conducted to get qualitative data related to the challenges of teachers in giving verbal positive reinforcement. Another purpose of FGD was to clarify and verify quantitative data got using the survey. FGD was conducted online using zoom application by involving 20 teachers (10 male and 10 female teachers).

\section{Research Instrument}

To measure the intensity of positive reinforcement they gave during school from home, we developed an instrument containing 7 kinds of verbal positive reinforcements that can be given by teachers during school from home. This instrument was developed according to the theory of positive reinforcement by Skinner (1953) and Schakel and Lyon (1984) using the semantic differential method. This instrument consists of 10 
different responses; 1 is the lowest score, meaning the teacher never giving positive reinforcement. At the same time, 10 is the highest score indicating that teacher very frequently giving positive reinforcement to students during school from home. The results of the validity test showed that all items had a correlation value above 0.30 , and Cronbach alpha value of the instrument reliability was 0.75 .

\section{Data Analysis}

Data were analyzed using descriptive and inferential statistical techniques by SPSS application. The descriptive statistic was to measure the intensity of teachers to give positive reinforcement. At the same time, the inferential statistic, which in this case was the independent sample t-test had the purpose of identifying the significance of the difference between male and female teachers in addressing positive reinforcement.

\section{FINDINGS AND DISCUSSION}

\section{Platforms used by teachers during School from Home}

The enactment of school from home regulation required teachers to use and applied technologies for distance learning. Some platforms generally used by teachers during School from Home are presented in Figure 1.

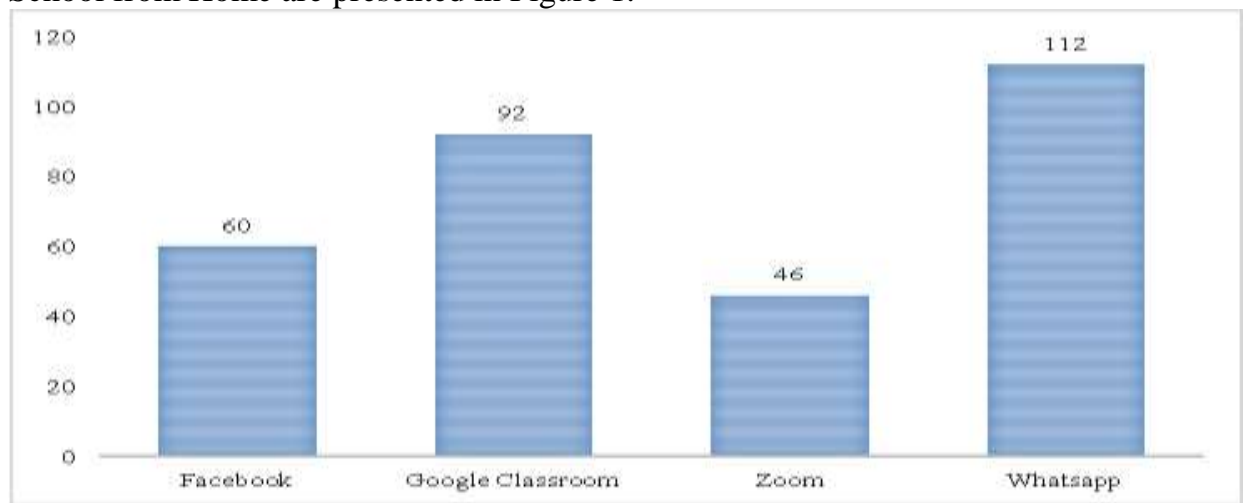

Figure 1

Some platforms generally used by teachers

Figure 1 shows that WhatsApp media was the most common platform used by teachers. One of the reasons was that WhatsApp was that this application was easy to use; thus most students and parents could use it. Besides that, it was cheaper compared to other applications. These were the reason why this app was mostly preferred as learning media during school from home. However, obviously, there were some weaknesses this media had compared to other platforms like google classroom or zoom. The type of platform used by teachers in teaching affected the intensity or kinds of positive reinforcement they could give to students. For example, when teachers were using google classroom or the like, they could not give oral positive reinforcement. While when teachers used WhatsApp or Facebook as teaching media, they would be only able to give oral positive reinforcement. 


\section{Forms of Positive Communication Reinforcement by Teachers}

The findings of the study showed that there were some forms of verbal and written positive reinforcement from teachers to students while undergoing school from home. For a more detailed, look at table 2.

Table 2

Forms of positive communication reinforcement by teachers

\begin{tabular}{|c|c|c|c|c|c|c|c|c|c|c|c|c|}
\hline \multirow[t]{2}{*}{ No } & \multirow{2}{*}{$\begin{array}{l}\text { Forms of Positive } \\
\text { Reinforcement }\end{array}$} & \multicolumn{10}{|c|}{ Respond (\%) } & \multirow[t]{2}{*}{ Mean } \\
\hline & & 1 & 2 & 3 & 4 & 5 & 6 & 7 & 8 & 9 & 10 & \\
\hline 1 & $\begin{array}{l}\text { Asking students' } \\
\text { condition in each } \\
\text { meeting }\end{array}$ & 0 & 24.52 & 21.94 & 44.19 & 9.35 & 0 & 0 & 0 & 0 & 0 & 3.38 \\
\hline 2 & $\begin{array}{l}\text { Giving a compliment } \\
\text { to students who get a } \\
\text { high score in a test, } \\
\text { quiz, or task }\end{array}$ & 0 & 0 & 1.94 & 20.32 & 34.52 & 20.97 & 22.26 & 0 & 0 & 0 & 5.41 \\
\hline 3 & $\begin{array}{l}\text { Giving a compliment } \\
\text { to students who } \\
\text { always submit tasks } \\
\text { on time }\end{array}$ & 0 & 9.68 & 26.45 & 45.48 & 18.39 & 0 & 0 & 0 & 0 & 0 & 3.72 \\
\hline 4 & $\begin{array}{l}\text { saying thanks to } \\
\text { students, as they have } \\
\text { submitted their task, } \\
\text { helped teachers, } \\
\text { performed other } \\
\text { positive attitudes. }\end{array}$ & 0 & 0 & 0 & 25.81 & 18.71 & 21.29 & 34.19 & 0 & 0 & 0 & 5.63 \\
\hline 5 & $\begin{array}{l}\text { Giving a compliment } \\
\text { to students when they } \\
\text { are brave to express } \\
\text { their ideas }\end{array}$ & 0 & 0 & 2.26 & 19.03 & 23.23 & 27.42 & 28.06 & 0 & 0 & 0 & 5.6 \\
\hline 6 & $\begin{array}{l}\text { Giving a compliment } \\
\text { to students who } \\
\text { always come on time } \\
\text { at each meeting }\end{array}$ & 0 & 16.77 & 27.42 & 48.39 & 7.42 & 0 & 0 & 0 & 0 & 0 & 3.46 \\
\hline 7 & $\begin{array}{l}\text { Motivating students } \\
\text { during undergoing } \\
\text { School from Home }\end{array}$ & 0 & 0 & 0 & 19.03 & 23.87 & 22.58 & 34.52 & 0 & 0 & 0 & 5.72 \\
\hline
\end{tabular}

As explained before, the instruments of this study used a semantic differential scale consisting of 10 intervals. Score 1 was the minimum score meaning that teachers never gave positive reinforcement to students, and score 10 was the maximum score indicating that teachers very frequently gave positive reinforcement. Table 2 shows that all respondents had ever given positive reinforcement to their students during school from home. It is indicated by the absence of teachers giving score 1 in each instrument item. Although all teachers had ever given positive reinforcement, none of them had given it in high intensity. It is indicated by the absence of teachers giving score 8,9 , or 10 in any instrument item. The data indicate that the frequency of positive reinforcements from teachers was mostly in the 'less' category.

Some earlier studies showed different findings of the intensity of positive reinforcement given in the learning process. Conroy et al. (2009) showed that most teachers at 
elementary schools are used to give positive reinforcement in the learning process. Similar findings were reported by Anderson \& Spaulding (2007) and Uddin et al. (2017). Both studies showed that teachers do not only give positive reinforcement but also may give negative reinforcement in the learning process depending on the situation of the classroom. The difference between studies conducted by Conroy et al. (2009), Anderson \& Spaulding (2007), Uddin et al. (2017), and the current research was the situation and condition during the learning process. This study was carried out during the COVID 19 pandemic causing all learning activities conducted online. It potentially brought findings different from to the previous ones.

Interviews conducted with teachers showed the low frequency of giving positive reinforcement was due to some factors. One of them was that teachers did not really understand the urgency to give positive reinforcement to students in the pandemic situation. Teachers tended to focus on how to deliver teaching materials to students only. This is in line with earlier studies showing that the way teachers communicate to students is a variable that is not prioritized by teachers in the learning process (Mantasiah \& Yusri, 2017). Other findings showed that teachers tended to define the reward in positive reinforcement like toys, food, or other gifts. Many of them did not understand that positive reinforcement could be utterances like saying thanks, asking conditions, giving compliments, and so on.

Data in table 2 also shows that each teacher tended to give the same positive reinforcement. For example, in item 1 "Asking students' condition in each meeting" no teacher was giving a score of 5 or above. It means that this positive reinforcement form was seldom given by teachers. The data obtained from the interview showed that teachers perceived it to be not really important and only took up the learning duration. Therefore, they only checked students' attendance in every meeting before teaching. This factor led teachers seldom to reinforce students with item number 1. Differently from the positive reinforcement number 4, "saying thanks to students who performed a positive attitude", there was no teacher giving score 4 and below. It means that this positive reinforcement form was more frequently given to students compared to others. Culture to say thanks was one of the materials in character education taught to students at the elementary school level. Teachers were demanded to teach and habituate their students to say thanks as one of the positive characters that had to be possessed by each student. One of the best ways to teach the culture is by practising it to students. This factor caused the intensity of teachers to give positive reinforcement using item 4 quite higher compared to other items.

Most teachers were not aware that saying thank you to students when they performed a positive attitude was one of positive reinforcement. The data strengthen the previous finding that teachers had a lack of understanding about verbal positive reinforcement. For more detailed information, the intensity of positive reinforcement given by teachers according to the forms is presented in Figure 2. To understand the figure, we should notice that the maximum score of each item is 10 while the minimum score is 1 , so that the median score is 5 . 


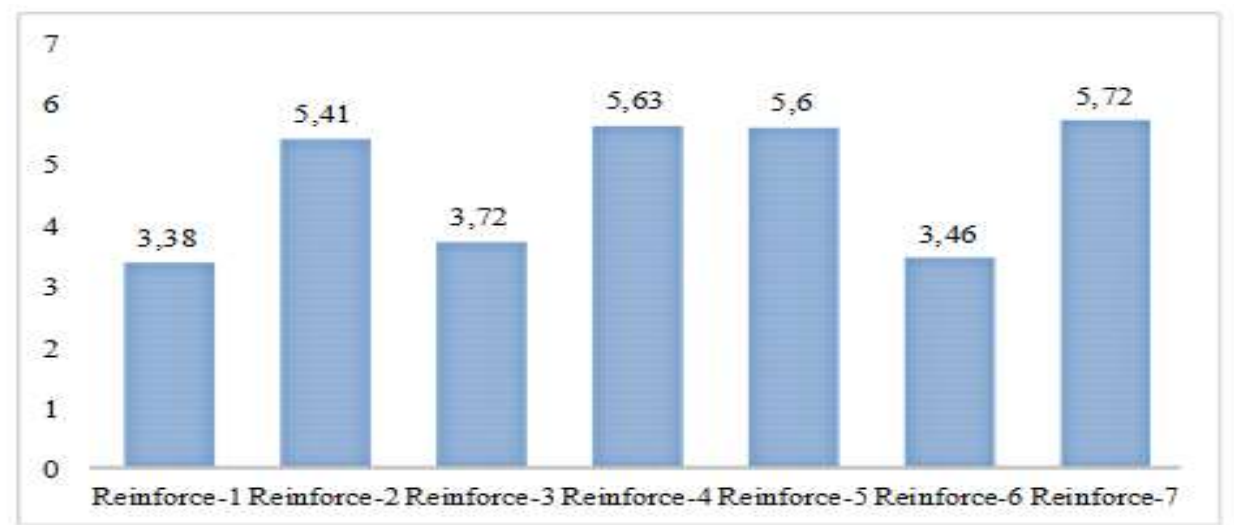

Figure 2

The intensity of positive reinforcement

The findings show that 4 kinds of positive reinforcement got a mean score above the median, namely items $7,4,5$, and 2 . It means that those four positive reinforcements were sometimes or quite frequently delivered by teachers to students during school from home. This support was given by teachers to make students endure to be at home and able to keep focus to study at home. However, positive reinforcement using items 3,6 , and 1 got the mean scores below the median. It means that teachers seldom or rarely showed those three forms. The kind of positive reinforcement that got the lowest frequency was asking students' conditions in each meeting. As it has been explained before that teachers perceived it not as a priority and they did not understand that asking students' condition could be categorized as positive reinforcement.

Although the intensity of teachers to give positive reinforcement was in a low category, researchers identified some forms or examples of positive reinforcement that teachers had given to their students while undergoing the school form home. These reinforcements were delivered to students both in oral and written forms. Following are some oral and written utterances used by teachers that can be categorized as verbal positive reinforcement:

1. 'How's life all? Hopefully, everyone's fine.

Data above is one of the utterances in written forms delivered by a teacher to students in a WhatsApp group. Based on the utterance above, we can see that the teacher tried to show his/her sympathy to students by trying to know each of the students' information. The data above was included as positive reinforcement item 1.

2. "I have checked your video tasks, and they are interesting. But, the video made by Aini is the best, therefore, I'm going to share it to other class groups"

The data above was also a written utterance delivered through the WhatsApp group. Based on the data, it can be concluded that the teacher tried to give compliments to all students, and the teacher also gave higher appreciation to one of her/his students related to her/his work. The data above were categorized as positive reinforcement item 2 . 
3. "Don't forget to upload your task, the deadline is tomorrow evening. Mita, Salwan, and Naura have submitted their tasks earlier, Great!

The data above was posted by a teacher in a WhatsApp group to remind students about their tasks. The teacher gave a compliment to some students because they had submitted their tasks before the deadline. Data above is a kind of positive reinforcement item 3 .

4. "Thank you, your task has been in the email"

Data above is a fragment of conversation between a teacher and a student. A student confirmed to his teacher that he had emailed the task, and the teacher replied to his message as above. Saying thanks to students is also a positive reinforcement because students will feel appreciated. The data above is categorized as positive reinforcement type 4.

5. "Let's give applause to Randy because he has talked about his experience during school from home".

The data above was delivered orally by a teacher when he /she taught using a zoom app. Based on the data, it can be concluded that the teacher gave appreciation to one of the students by inviting other students to give applause. The data above is categorized as positive reinforcement item 5 .

6. 'I'll base students' attendance based on their task. So far, there have been some students completed all tasks, which means that they have full attendances, like Andi Sahwan, Puput Permatasari, Eka Prilia, Ananda Citra Pertiwi,

Data above was delivered by the teacher though a WhatsApp group in the last meeting before the semester exam. Based on the data, it can be concluded that the teacher gave a compliment to students who always attended meetings. The data above is categorized as positive reinforcement item 6.

7. “Although you don't go to school, you must continue to study hard at home. Your parents and siblings can accompany you.

Data above was a written utterance posted by a teacher in the students' WhatsApp group. The sentence shows that the teacher tried to support students to keep diligent studying at home, although there was no teacher directly guiding them. The data above is categorized as positive reinforcement item 7 .

\section{The difference between male and female teachers in giving reinforcement}

Other findings showed that male and female teachers had a difference in giving positive reinforcement during school from home.

Table 3

Comparison of the mean scores between male and female teachers

\begin{tabular}{llllll}
\hline Group Statistics & & & & & \\
\hline & Sex & $\mathrm{N}$ & Mean & Std. Deviation & Std. Error Mean \\
\hline Reinforcement & Men & 128 & 32.34 & 2.944 & .260 \\
\cline { 2 - 6 } & Women & 182 & 33.38 & 2.677 & .198 \\
\hline
\end{tabular}

The intensity of female teachers in giving verbal positive reinforcement was higher than male teachers. It can be seen from the comparison of the mean score in table 3 . The level of significant difference between male and female teachers in giving positive reinforcement can be seen in table 4. 
Table 4

Results of independent sample T-Test analysis

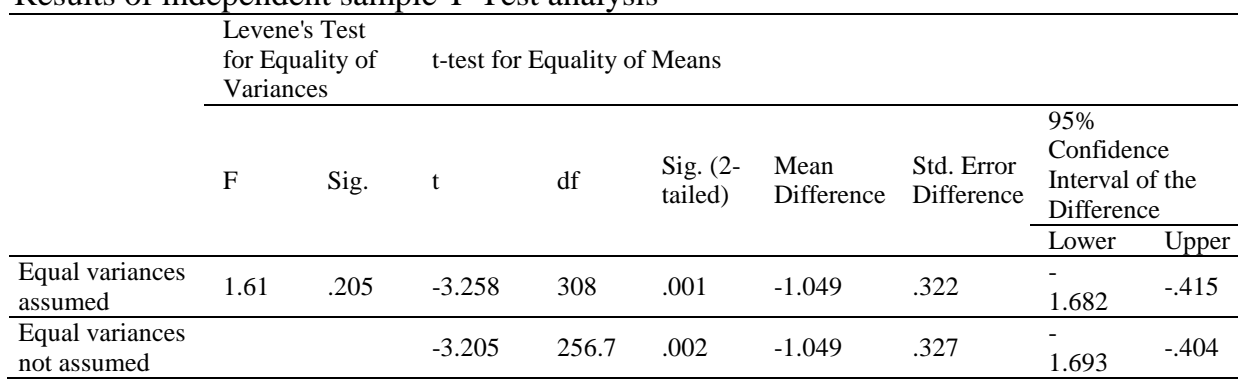

Table 4 shows that the variance between male and female teachers was homogenous. It can be seen from the value of sig Levene's Test for Equality of Variances (0.205) that is bigger than 0.05 . The significance value of item equal variables assumed $(0.001)$ that is smaller than 0.05 , meaning there was a significant difference in the intensity between male and female teachers in giving verbal positive reinforcement to students during school from home. Besides that, the kinds of positive reinforcement given by male and female teachers were different. The findings showed that male teachers tended to give positive reinforcement by saying thanks as in item 4, and gave support or motivation as in item 7. At the same time, female teachers to reinforce students more by giving compliment than saying thanks.

The findings of the current study were different from Hoon et al. (2017) showing that there was no strong evidence supporting the significant difference of the communication skills between genders. This study also involved elementary school teachers as respondents. However, the main focus of Hoon's study was more general that in this case, it compared the communication skills of teachers in classroom management. His study found that there is a significant difference in the communication skills between male and female teachers. However, the differences in teachers' communication skills are affected by the classroom management methods they use. Based on Hoon et al. (2017) findings, it can be concluded that teachers' communication skills depend on the classroom management used by the teacher. It confirmed the study of Ozkan et al. (2014) that compared the communication skills of male and female candidate teachers. They concluded that there is no significant difference between the communication skills of male and female candidate teachers.

Differently from Hoon et al. (2017) and Ozkan et al. (2014), the study conducted by Tench et al. (2017) showed a significant difference between the number of positive utterances produced by men and women, which in this case, the women are dominant. The positive utterances here refer to speech willing to be heard by interlocutors like a compliment or positive support. It is in line with the finding of the current study that female teachers tended to give positive reinforcement through compliment compared to male teachers more frequently. Nelson's study in (Sinaga \& Husein, 2018) also showed a similar finding that students believe that their female teachers are more sensitive and consider more their ideas compared to their male teachers. Besides that, Furumo \& 
Pearson (2007) stated that the communication patterns of men and women are different. Female teachers usually build a better relationship and connection compared to male teachers. One of their ways to make a connection with their students is by giving a compliment when they behave positively, or regularly asking students' condition. Some of these studies showed that the communication styles of male and female teachers tend to be different. In the context of positive reinforcement, female teachers are more intensive to give positive reinforcement to build connections or to familiarize themselves with their students.

\section{Study Limitations}

There are some limitations of this study and these limitations can be suggestion for the further study. 310 samples seems too small to confirm significance of finding. Therefore, the number of sample can be increased for the next study. Due to pandemi situation, focus group discussion was conducted online using zoom platform. It will be difference if we conduct FGD directly, researcher can get data deeper from participants.

\section{CONCLUSION}

The research findings showed that while carrying out teaching with school from home concept, teachers tended to give less verbal positive reinforcement to students. Teachers' lack of understanding about the urgency to give positive reinforcement in the learning process during the pandemic became the main factor causing the intensity of teachers to give positive reinforcement less or not frequently. Besides that, teachers did not understand that positive reinforcement can be given verbally both in oral and written forms. The less supporting learning facilities also became a factor causing the lack of positive verbal reinforcement. Most teachers used WhatsApp or other social media in the learning process, and they believed that it was impossible to give direct positive reinforcement to students, that were different from the zoom app or other similar apps. Another finding shows that female teachers tend to give more positive reinforcement than male teachers. The kinds of positive reinforcement given by male and female teachers also tend to be different.

\section{ACKNOWLEDGEMENT}

This study was funded by the Ministry of Research and Technology/National Research and Innovation Agency (RISTEK-BRIN) of the Republic of Indonesia through the research grant (PTUPT) (Grant Number: 2251/UN36.11/LP2M/2020).

\section{REFERENCES}

Alberto, P. A., \& Troutman, A. C. (2006). Applied behavior analysis for teachers (7th ed.). Upper Saddle River, NJ: Pearson.

Altig, D., Baker, S., Barrero, J. M., Bloom, N., Bunn, P., Chen, S., ... \& Mizen, P. (2020). Economic Uncertainty before and during the COVID-19 Pandemic. Journal of Public Economics, 104274. 
Anderson, C. M., \& Spaulding, S. A. (2007). Using Positive Behavior Support to Design Effective Classrooms. Beyond Behavior, 16(2), 27-31.

Bernier, S., Simpson, C. G., \& Rose, C. A. (2012). Positive and Negative Reinforcement in Increasing Compliance and Decreasing Problematic Behavior. National Teacher Education Journal, 5(1), 45-51.

Chen, H., Guo, J., Wang, C., Luo, F., Yu, X., Zhang, W., ... \& Liao, J. (2020). Clinical characteristics and intrauterine vertical transmission potential of COVID-19 infection in nine pregnant women: a retrospective review of medical records. The Lancet, 395(10226), 809-815.

Cicekci, M. A., \& Sadik, F. (2019). Teachers' and Students' Opinions About Students' Attention Problems During the Lesson. Journal of Education and Learning, 8(6), 15-30. https://doi.org/10.5539/jel.v8n6p15

Conroy, M. A., Sutherland, K. S., Snyder, A., Al-Hendawi, M., \& Vo, A. (2009). Creating a positive classroom atmosphere: Teachers' use of effective praise and feedback. Beyond Behavior, 18(2), 18-26.

Courtemanche, C., Garuccio, J., Le, A., Pinkston, J., \& Yelowitz, A. (2020). Strong Social Distancing Measures In The United States Reduced The COVID-19 Growth Rate: Study evaluates the impact of social distancing measures on the growth rate of confirmed COVID-19 cases across the United States. Health Affairs, 39(7), 1237-1246. https://doi.org/10.1377/hlthaff.2020.00608

Creswell, J. W., \& Clark, V. L. P. (2017). Designing and conducting mixed methods research. London: Sage publications.

Furumo, K., \& Pearson, J. M. (2007). Gender-based communication styles, trust, and satisfaction in virtual teams. Journal of Information, Information Technology \& Organizations, 2, 47-60. https://doi.org/10.28945/138

Greenstone, M., \& Nigam, V. (2020). Does social distancing matter? SSRN Electronic Journal, 2020 (26), 1-19. https://doi:10.2139/ssrn.3561244

Hardy, J. K., \& McLeod, R. H. (2020). Using Positive Reinforcement With Young Children. Beyond Behavior, 9(2), 95-107. https://doi.org/10.1177/1074295620915724

Hoon, T. S., Nasaruddin, N. F. B. M., \& Singh, P. (2017). Communication Skills among Different Classroom Management Styles Teachers. Asian Journal of University Education, 13(1), 67-78.

Hoque, R. (2013). Effect of reinforcement on teaching-learning process. IOSR Journal Of Humanities And Social Science, 7(1), 13-16. https://doi.org/10.9790/0837-0711316

Hulac, D., Benson, N., Nesmith, M. C., \& Wollersheim Shervey, S. (2016). Using variable interval reinforcement schedules to support students in the classroom: An introduction with illustrative examples. Journal of Educational Research and Practice, 6(1), 90-96. https://doi.org/10.5590/jerap.2016.06.1.06 
Kelly, J., \& Pohl, B. (2018). Using structured positive and negative reinforcement to change student behavior in educational settings in order to achieve student academic success. Multidisciplinary Journal for Education, Social and Technological Sciences, 5(1), 17-29. https://doi.org/10.4995/muse.2018.6370

Kodak, T., Lerman, D. C., Volkert, V. M., \& Trosclair, N. (2007). Further examination of factors that influence preference for positive versus negative reinforcement. Journal of Applied Behavior Analysis, 40(1), 25-44. https://doi.org/10.1901/jaba.2007.151-05

Mantasiah, M., \& Yusri, Y. (2017). The Influence of Teacher's Language Politeness in Improving Student's Academic Motivation. In 8th International Conference of Asian Association of Indigenous and Cultural Psychology (ICAAIP 2017). Atlantis Press.

Murni, Wahid. (2010). Keterampilan Dasar Mengajar. Yogyakarta: Ar Ruzz Media.

Nicola, M., Alsafi, Z., Sohrabi, C., Kerwan, A., Al-Jabir, A., Iosifidis, C., ... \& Agha, R. (2020). The socio-economic implications of the coronavirus and COVID-19 pandemic: a review. International Journal of Surgery, 78, 185-193. https://doi.org/10. 1016/j.ijsu.2020.04.018

Onder, G., Rezza, G., \& Brusaferro, S. (2020). Case-fatality rate and characteristics of patients dying in relation to COVID-19 in Italy. Jama, 323(18), 1775-1776. https://doi.org/10.1001/jama.2020.4683

Ozkan, H., Dalli, M., Bingol, E., Metin, S. C., \& Yarali, D. (2014). Examining the relationship between the communication skills and self-efficacy levels of physical education teacher candidates. Procedia-Social and Behavioral Sciences, 152, 440-445. https://doi.org/10.1016/j.sbspro.2014.09.228

Prem, K., Liu, Y., Russell, T. W., Kucharski, A. J., Eggo, R. M., Davies, N., ... \& Abbott, S. (2020). The effect of control strategies to reduce social mixing on outcomes of the COVID-19 epidemic in Wuhan, China: a modelling study. The Lancet Public Health, 5(5), 261-270. https://doi.org/10.1016/S2468-2667(20)30073-6

Purwanto, A., Pramono, R., Asbari, M., Hyun, C. C., Wijayanti, L. M., \& Putri, R. S. (2020). Studi Eksploratif Dampak Pandemi COVID-19 Terhadap Proses Pembelajaran Online di Sekolah Dasar. EduPsyCouns: Journal of Education, Psychology and Counseling, 2(1), 1-12.

Rundle, A. G., Park, Y., Herbstman, J. B., Kinsey, E. W., \& Wang, Y. C. (2020). COVID-19-Related School Closings and Risk of Weight Gain Among Children. Obesity, 28(6), 1008-1009. https://doi.org/10.1002/oby.22813

Schakel, J. A., \& Lyon, M. A. (1984). Positive reinforcement and logical consequences in the treatment of classroom encopresis. School Psychology Review, 13(2), 238-243.

Sigler, E. A., \& Aamidor, S. (2005). From positive reinforcement to positive behaviors: An everyday guide for the practitioner. Early Childhood Education Journal, 32(4), 249253. https://doi.org/10.1007/s10643-004-0753-9 
Sinaga, M., \& Husein, R. (2018). Teachers' Language Style with Reference to Sex Differences in Teaching English. In 3rd Annual International Seminar on Transformative Education and Educational Leadership (AISTEEL 2018). Atlantis Press.

Skinner, B.F. (1953). Science and human behaviour. New York: Macmillan.

Sumiati, T., Septiani, N., Widodo, S., \& Caturiasari, J. (2019). Building children's learning motivation through positive reinforcement in science and math classroom. In Journal of Physics: Conference Series (Vol. 1318, No. 1, p. 012023). IOP Publishing.

Tench, R., Topić, M., \& Moreno, A. (2017). Male and female communication, leadership styles and the position of women in public relations. Interactions: Studies in Communication \& Culture, 8(2-3), 231-248. https://doi.org/10.1386/iscc.8.2-3.231_1

Ting, D. S. W., Carin, L., Dzau, V., \& Wong, T. Y. (2020). Digital technology and COVID-19. Nature medicine, 26(4), 459-461. https://doi.org/10.1038/s41591-0200824-5

Uddin, M. R., Hena, S., \& Shanil, A. H. (2017). Influence Of Reinforcement In English Language Learning at Primary Level of Education in Bangladesh. BELTA Journal, 1(1), 85. https://doi.org/10.36832/10.36832/beltaj.2017.0101.05

Van Lancker, W., \& Parolin, Z. (2020). COVID-19, school closures, and child poverty: a social crisis in the making. The Lancet Public Health, 5(5), 243-244. https://doi.org/10.1016/s2468-2667(20)30084-0

Viner, R. M., Russell, S. J., Croker, H., Packer, J., Ward, J., Stansfield, C., ... \& Booy, R. (2020). School closure and management practices during coronavirus outbreaks including COVID-19: a rapid systematic review. The Lancet Child \& Adolescent Health, 4(5), 397-404. https://doi.org/10.1016/s2352-4642(20)30095-X

Wang, C. J., Ng, C. Y., \& Brook, R. H. (2020). Response to COVID-19 in Taiwan: big data analytics, new technology, and proactive testing. Jama, 323(14), 1341-1342. https://doi.org/10.1001/jama.2020.3151

Wang, G., Zhang, Y., Zhao, J., Zhang, J., \& Jiang, F. (2020). Mitigate the effects of home confinement on children during the COVID-19 outbreak. The Lancet, 395(10228), 945-947. https://doi.org/10.1016/s0140-6736(20)30547-x

Zirpoli, T. J. (2005). Behavior management: Applications for teachers (4th ed.). In A. P. Sharp \& K. S. Burk (Eds.), Establishing a reinforcement program (pp.189-224). Upper Saddle River, NJ: Prentice Hall. 